\title{
The Dutch energy transition approach
}

\section{René Kemp}

Published online: 23 June 2010

(C) The Author(s) 2010. This article is published with open access at Springerlink.com

\begin{abstract}
The article describes the Dutch energy transition approach as an example of an industrial policy approach for sustainable growth. It is a corporatist approach for innovation, enrolling business in processes of transitional change that should lead to a more sustainable energy system. A broad portfolio of options is being supported. A portfolio of options is generated in a bottom-up, forward looking manner in which special attention is given to system innovation. Both the technology portfolio and policies should develop with experience. The approach is forward-looking and adaptive. One might label it as guided evolution with variations being selected in a forward-manner by knowledgeable actors willing to invest in the selected innovations, the use of strategic learning projects (transition experiments) and the use of special programmes and instruments. Initially, the energy transition was a selfcontained process, largely separated from existing policies for energy savings and the development of sustainable energy sources. It is now one of the pillars of the overall government approach for climate change. It is a promising model but economic gains and environmental gains so far have been low. In this article I give a detailed description of the approach and an evaluation of it.
\end{abstract}

\section{Introduction}

The term transition is employed by various scholars and organisations working on sustainable development. The first book containing these terms was the book The Transition to Sustainability. The Politics of Agenda 21 in Europe, edited by Timothy O'Riordan and Heather Voisey, published in 1998. This book was followed by two other books which similar titles: Our Common Journey: A transition toward sustainability by The Board on Sustainable Development of the US National

Acknowledgement The author wants to thank the reviewers and the editor for their comments.

R. Kemp $(\bowtie)$

UNU-MERIT, Maastricht, The Netherlands

e-mail: r.kemp@maastrichtuniversity.nl

R. Kemp

ICIS, Maastricht, The Netherlands 
Research Council (NRC 1999) and Sustainable development: The challenge of transition edited by Jurgen Schmandt and C.H. Ward (2000) contained contributions from Frances Cairncross, Herman Daly, Stephen Schneider which came out in 2000.

In all three books the term transition is used as a general term, not as a theoretical organizer.

In the last 8 years various articles appeared in which the term transition is explored and used in a more theoretical sense. The new literature consisted of historical studies looking back at past transitions using a multilevel perspective (Geels 2002, 2005, 2006, 2007), theoretical deliberations about transitions (Geels 2002, 2004; Berkhout et al. 2004; Smith et al. 2005; Geels and Schot 2007; Genus and Cowes 2008), and deliberations about steering societies towards more sustainable systems of provision and associated practices (Rotmans et al. 2001; Grin 2006; Kemp and Loorbach 2006; Kemp et al. 2007a, b; Loorbach 2007; Shove and Walker 2007, 2008; Rotmans and Kemp 2008; Smith and Stirling 2008; Holtz et al. 2008; Foxon et al. 2009). People in this literature are concerned with transformative change (system innovation), drawing on a co-evolutionary perspective, with technology and society mutually shaping each other, instead of one more or less determining the other. ${ }^{1}$ This article will do two things: a) it will describe transition thinking (Section 2) and b) it will describe attempts by the Dutch government to apply transition thinking in the area of energy (Section 3). A reflection and tentative evaluation of transition policy is offered in Section 4.

\section{Transition thinking in the Netherlands}

In this section we give an overview of transition research and thinking in the Netherlands. The Dutch "transition to sustainability" literature is concerned with fundamental changes in functional systems of provision and consumption. It involves contributions from innovation researchers, historians of technology, political scientists and systems analysts. It is not rooted in one discipline and people tend to be multidisciplinary (some are even transdisciplinary which means that they are working with practitioners). Basically there are four traditions: the work on sociotechnical transitions by Frank Geels and others, the work on transition management by Jan Rotmans and others, the work on social practices and systems of provision by Gert Spaargaren and others, and the work on reflexive modernisation by John Grin and others. People in those traditions are cooperating in the Dutch KSI programme on system innovation and transition. Each of the traditions will be briefly described.

\subsection{The sociotechnical approach}

The sociotechnical transition approach is created in Twente by Arip Rip and Johan Schot, and was used by historians in a big research programme about the history of technology in the Netherlands. It is based on a co-evolutionary view of technology and society and a multilevel perspective (Rip and Kemp 1998; Geels 2002, 2004; Hoogma et al. 2002). The co-evolutionary holds that technology and society

\footnotetext{
${ }^{1}$ Various contributions on the idea of co-evolution steering for sustainable development can be found in the special issue of The International Journal of Sustainable Development and World Ecology.
} 
codetermine each other and that the interactions give rise to irreversible developments and path dependencies. The multilevel perspective is an attempt to bring in structures and processes of structuring into the analysis through the use of the following three elements: the sociotechnical landscape, regimes, and niches.

The socio-technical landscape relates to material and immaterial elements at the macro level: material infrastructure, political culture and coalitions, social values, worldviews and paradigms, the macro economy, demography and the natural environment. Within this landscape we have sociotechnical regimes and special niches.

Sociotechnical regimes are at the heart of transition scheme. The term regime refers to the dominant practices, search heuristics, outlook or paradigm and ensuing logic of appropriateness pertaining in a domain (a sector, policy domain or science and technology domain), giving it stability and orientation, guiding decision-making. Regimes may face landscape pressure from social groups objecting to certain features (pollution, capacity problems and risks) and may be challenged by niche developments consisting of alternative technologies and product systems. Faced with these pressures, regime actors will typically opt for change that is non-disruptive from the industry point of view, which leads them to focus their attention to system improvement instead of system innovation.

A visual representation of the multilevel model is given in Fig. 1. taken from Rip and Kemp (1996), indicating three important processes: 1) the creation of novelties at the microlevel against the backdrop of existing (well-developed) product regimes, 2) the evolution of the novelties, exercising counter influence on regimes and landscape, 3) the macro landscape which is gradually transformed as part of the process occurring over time (X-axis).

The key point (basic hypothesis) of the multi-level perspective (MLP) is that transitions come about through the interplay between processes at different levels in different phases. ${ }^{2}$ In the first phase, radical innovations emerge in niches, often outside or on the fringe of the existing regime. There are no stable rules (e.g. dominant design), and actors improvise, and engage in experiments to work out the best design and find out what users want. The networks that carry and support the innovation, are small and precarious. The innovations do not (yet) form a threat to the existing regime. In the second phase, the new innovation is used in small market niches, which provide resources for technical development and specialisation. The new technology develops a technical trajectory of its own and rules begin to stabilise (e.g. a dominant design). But the innovation still forms no major threat to the regime, because it is used in specialised market niches. New technologies may remain stuck in these niches for a long time (decades), when they face a mis-match with the existing regime and landscape. The third phase is characterised by wider breakthrough of the new technology and competition with established regime, followed by a stabilisation and new types of structuring.

A transition example is the transition from coal to natural gas in the Netherlands for space heating. ${ }^{3}$ Here multiple developments coincided; the discovery of large amounts of natural gas in the Netherlands at the end of the 1950s, experience with large-scale production and distribution of gas produced in coke factories, cheap imports of coal which made Dutch coal production unprofitable. Furthermore with

\footnotetext{
${ }^{2}$ This section comes from Geels and Kemp (2007).

${ }^{3}$ Based on Rotmans et al. (2000, 2001) who based themselves on Verbong (2000).
} 


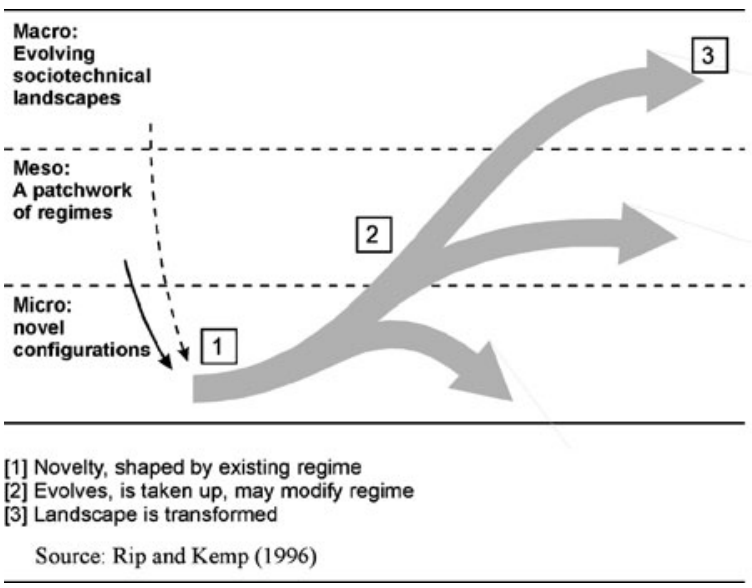

Fig. 1 The multilevel model of innovation and transformation. Source: Rip and Kemp (1996)

the rise of nuclear power, there was also a general expectation that the price of energy was about to fall sharply. So when a large gas field was discovered in Slochteren in 1959, exploiting it became a political priority.

Important meso factors were the creation of a state gas company, the Staatsgasbedrijf, for the distribution of gas, and a national gas company, the Nationale Gas Maatschappij, for the supply of gas. The creation of these companies was resented by local councils and the semi-nationalized companies (Hoogovens and Dutch State Mines-DSM) who did not want to give up their power. However, after tough negotiations of government with oil companies Shell and Esso (now Exxon), the gas supply became the monopoly of the Gasunie (Gas Association), whose shares were owned by the state and the two oil companies. Under the supervision of the Gasunie, local councils retained responsibility for distribution. Hoogovens was bought out and DSM was included in the Gasunie on behalf of the government as a compensation for the closing of the mines.

Households were sold to the idea of using natural gas, thanks to campaigns. By international standards, the condition of the Netherlands' housing stock was poor. Houses were uncomfortable, lacked insulation and were poorly heated, representing a (large-scale) socio-technical niche. People wanted the comforts of central heating and warm water for showers/baths. By the end of the 1960s, the transformation was complete: the gas supply was based fully on natural gas and controlled by the Gasunie.

The transition from coal to natural gas in the Netherlands is an example of a government-induced (one could say managed) transition. The Dutch government had clear objectives and sub-objectives, which resulted in a very quick and relatively smooth transition. Such a goal-oriented transition is rather exceptional; most transitions are the outcome of the many choices of myopic actors who do not based their decisions on a clear long-term view.

The transition scheme has been refined and used by Frank Geels and others in a series of studies. This work resulted in several theoretical innovations: the identification of 4 transition patterns (transformation, de-alignment and re-alignment, technological substitution and reconfiguration) (Geels and Schot 2007) and the distinction between local and global elements in the development of new trajectories Geels and Raven (2007). More attention is also given to the interplay between multiple regimes 
(Verbong and Geels 2007) and interplay of functions in the development of technological innovation systems (Jacobsson and Bergek 2004; Hekkert et al. 2007; Bergek et al. 2008; Markard and Truffer 2008).

Most of the work is retrospective, based on secondary sources, but the multilevel perspective has also been applied prospectively, for example by Verbong and Geels (2008). The authors are all based in Eindhoven (in 2008 Frank Geels moved to SPRU in the UK). Much attention is given to technology aspects, because they are focussing their studies on transformations in which technology is a key element. Geels studied the following transitions:

1. From sail to steamships UK (1840-1890)

2. From horse-drawn carriage to automobiles US (1870-1930)

3. From cesspools to sewer systems NL (1870-1930)

4. From pumps to piped water systems NL (1870-1930)

5. From traditional factories to mass production (1870-1930)

6. From crooner music to rock 'n' roll US (1930-1970)

7. From propeller-aircraft to jetliners US (1930-1970)

8. Transformation of Dutch highway system (1950-2000)

9. Ongoing transition in NL electricity system (1960-2004)

This type of research builds on the work of Mumford (1934[1957]), Landes (1969), Rosenberg (1982) and Freeman and Louçã (2001). The above work may be usefully labelled the sociotechnical transition approach, given its focus on the co-evolution of technology, organisation and society. Technology is seen both as an outcome and a driver of transformations.

\subsection{The transition management approach}

The second type of scholarship is rooted in systems theory and complexity theory and is very much concerned with issues of steering and governance. This approach may be called either the societal transition approach or the transition management approach. ${ }^{4}$ It is being associated with people at DRIFT (especially Jan Rotmans and Derk Loorbach) in Rotterdam in the Netherlands, who have been active in the formulating principles of transition management. ${ }^{5}$ I am part of both traditions, having worked with Frank Geels, Johan Schot and Arie Rip, and with Jan Rotmans and Derk Loorbach.

In the first study on transition and transition management (Rotmans et al. 2000), a transition is being defined as a gradual, continuous process of change where the structural character of a society (or a complex sub-system of society) is being transformed (Rotmans et al. 2000). Transitions are transformations processes that lead to a new regime with the new regime constituting the basis for further development. A transition is thus not the end of history but denotes a change in dynamic equilibrium. A transition is conceptualised as being the result of developments in different domains and the process of change is typically non-linear; slow change is followed by rapid change when concurrent developments reinforce each other, which again is followed

\footnotetext{
${ }^{4}$ It may be called the societal transition approach because it has a stronger focus on (societal) actors and political conflict as primary drivers of transformations.

${ }^{5}$ DRIFT stands for the Dutch Research Institute for Transitions.
} 
by slow change in the stabilisation stage. There are multiple shapes a transition can take but the common shape is that of a sigmoid curve such as that of a logistic (Rotmans et al. 2000, 2001).

The multilevel, multi-phase model of transition was developed in a project for the 4th National Environmental Policy Plan of the Netherlands. In the project called Transitions and Transition management, principles for transition management were developed by Jan Rotmans, René Kemp and Marjolein van Asselt, together with policy makers, which were.

- Long-term thinking as a framework of consideration for the short-term policy (at least 25 years).

- Thinking in terms of more than one domain (multi-domain) and different actors (multi-actor) at different scale levels (multi-level).

- A focus on learning and a special learning philosophy (learning-by-doing and doing-by-learning).

- Trying to bring about system innovation besides system improvement.

- Keeping open a large number of options (wide playing field).

(Rotmans et al. 2000, 2001)

Transition management is based on a story line that persistent problems require fundamental changes in social subsystems, which are best worked at in forwardlooking, yet adaptive manner, based on multiple visions. Transition management consists of a deliberate attempt to work towards a transition offering sustainability benefits, in a forward-looking, yet adaptive manner, using strategic visions and actions. The concept is situated between two different views of governance: the incremental 'learning by doing' approach and the blueprint planning approach. Governance aspects were worked out in later years in a number of publications (Dirven et al. 2002; Rotmans 2005; Kemp et al. 2007a, b; and Loorbach 2007). The various elements of transition management are combined into a model of multi-level governance by Loorbach (2007) which consists of three interrelated levels:

- Strategic level: visioning, strategic discussions, long-term goal formulation.

- Tactical level: processes of agenda-building, negotiating, networking, coalition building.

- Operational level: processes of experimenting, implementation.

Transition management tries to improve the interaction between different levels of government by orienting these more to system changes to meet long-term policy goals. It is about organizing a sophisticated process whereby the different elements of the transition management process co-evolve: the joint problem perception, vision, agenda, instruments, experiments and monitoring through a process of social learning (Loorbach 2007). Transition management should lead to different actor-system dynamics, with altered actor configurations, power-constellations and institutional arrangements that form a different selection environment wherein social innovations can mature more easily (Loorbach 2007).

The basic steering philosophy is that of goal-oriented modulation, not planningand-control. Transition management joins in with ongoing dynamics and builds on bottom-up initiatives. Different sustainability visions and pathways towards achieving them are being explored. Over time, the transition visions are to be 
adjusted as a result of what has been learned by the players in the various transition experiments. Based on a process of variation and selection new and better visions are expected to emerge, while others die out.

It is important to note that in the transition scheme, government and government is seen as part of transitions or transformations instead of an external force. Policy is influenced by the interests, values, beliefs and mental models within the societal systems it seeks to alter and by the values and beliefs of society at large. The new role of government is to act as a facilitator of transformative change, something it can do on the basis of powers granted to them.

\subsection{The social practices approach}

The third tradition is that of social practices. Following Giddens, social practices are taken as the central unit of analysis. The concept of social practice refers to "a routinized type of behaviour which consists of several elements, interconnected to one another: forms of bodily activities, forms of mental activities, 'things' and their use, a background knowledge in the form of understanding, know-how, states of emotion and motivational knowledge" (Reckwitz 2002, p. 249). A distinction is made between integrated practices such as cooking, work and vacation and diffuse practices, being relatively simple standardised practices such as shaking hands or steering a car. Integrated practices are being undertaken in socially and materially situated contexts the characteristics of which shape (but do no determine) these practices, which have an individual and social element.

The social practices approach has been developed into a transition approach by Spaargaren et al. (2007) using the notions of niche, regime and landscape. It analyses how transition processes take shape at the level of everyday-life, focussing on the connection points between consumers and providers (consumption junctions). One such connection point is the supermarket where people may find biological food in special corners, shelves, which may be part of a particular line of food products such as "pure and honest" products and who may or may not be singled out for attention by providers. Transitions refer to changes in regimes of housing, mobility, clothing and professional care. More than the other transition approaches attention is given to social and symbolic dimensions and the situational context of behaviour and decision making. Researchers in this tradition (for example Shove 2004; Spaargaren 2003) are interested in de-routinisation and re-routinisation of everyday practice.

\subsection{The reflexive modernisation approach}

The fourth tradition is that of reflexive modernisation. This tradition uses the term system innovation instead of the term transition. The focus of this work is on the governance aspects around transformative change, the values, strategies and beliefs of societal actors. Sustainable development is viewed as a project of reflexive modernisation. Researchers in this tradition are especially interested in normative disputes, processes of re-structuration and issues of legitimacy and power (See Grin 2006; Hendriks 2008). Meadowcroft, Shove, Walker, Bulkely, Smith, Stirling and Voss can be viewed as international representatives of this approach by emphasizing the importance of power, legitimacy and conflict. 
What these four traditions unite is:

- An interest in understanding the mechanisms and politics of transformative change offering sustainability benefits

- A co-evolutionary view on societal transitions, in which different evolutionary (evolving) systems are influencing each other.

There are differences in focus. Some researchers are more interested in understanding change than in how transitions may be managed (Geels), others are more interested in evaluating policy and governance arrangements (Hendriks, Kern, Howlett, Smith), and there are those who are primarily interested in offering guidance for the management of system change processes (Rotmans and Loorbach).

The scholars share a view that transitions defy control because they are the result of endogenous and exogenous developments in regimes and the macro-landscape: there are cross-over effects and autonomous developments. Technical change interacts with economic change (changes in cost and demand conditions), social change and cultural change, which means that in managing transitions one should look for virtuous cycles of reinforcement (positive feedback).

The term transition management is only used by people from the transition management school, where it is variously labelled as goal-oriented modulation, directed incrementalism, co-evolutionary steering and reflexive governance for sustainable development (Rammel and van den Bergh 2003; Kemp and Loorbach 2006; Kemp et al. 2007a). It is a form of multilevel governance that is concerned with the co-evolution of technology and society in specific domains.

In the Netherlands the national government is using transition thinking in its innovation policies. The transition approach is one of the pillars of the programme "Clean and Resource-Efficient" (In Dutch: Schoon en zuinig). In so doing they are using ideas from transition management. The next section will describe the Dutch transition approach for sustainable energy.

\section{The Dutch transition approach}

Concerns about the depletion of fossil fuels, dependencies on foreign suppliers, and climate change led policy makers in the Netherlands to gradually adopt a transition approach for sustainable energy, mobility, agriculture and resource use, which is novel and very interesting. It is interesting because of its focus on transformative change, its reliance on bottom-up processes and enrolment of business and other non-state actors in the transformation process. ${ }^{6}$

\footnotetext{
${ }^{6}$ First ideas about transition management were created in the project "Transitions and transition management" for the fourth National Environmental Policy Plan (NMP4). In this project, a group of scientists and policy makers met to discuss a new strategic framework. A description of the coproduction process can be found in Kemp and Rotmans (2009) and Smith and Kern (2009). After the project the TM model was further developed by Derk Loorbach and Jan Rotmans and more or less independently by the Ministry of Economic Affairs (a description and discussion of this is given by Loorbach 2007).
} 
The transition approach relies on guided processes of variation and selection. It makes use of "bottom-up" developments and long-term thinking. A set of 31 transition paths are being traversed (including biomass for electricity, clean fossil, micro cogeneration, energy-producing agricultural greenhouses). The government acts as a process manager, dealing with issues of collective orientation and interdepartmental coordination. It also takes on a responsibility for the undertaking of strategic experiments and programmes for system innovation. Control policies are part of the transition approach but the government does not seek to control the process-it is not directing the process but seeks to facilitate learning and change.

At the heart of the energy transition project are the activities of 7 transition platforms. In these platforms individuals from the private and the public sector, academia and civil society come together to develop a common ambition for particular areas, develop pathways and suggest transition experiments.

The 7 platforms are:

- New gas

- Green resources

- Chain efficiency

- Sustainable electricity supply

- Sustainable mobility

- Built environment

- Energy-producing greenhouse

The transition approach officially started in 2002 with the project implementation transition management (PIT) of the Ministry of Economic Affairs |(EZ). In 20042005 , the energy transition process gained speed through the establishment of 4 platforms (new gas, green resources, chain efficiency and sustainable mobility), and the creation of the Interdepartmental Project directorate Energy transition (IPE). In 2006 two additional platforms were established (sustainable electricity supply and built environment). The transition path energy producing greenhouse became a platform of its own in 2008.

In the Interdepartmental Project directorate Energy transition (IPE) created in 2005 , issues of policy coordination are being discussed and dealt with by the secretary generals of six ministries: EZ responsible for innovation policy, energy policy and economic policy, VROM responsible for the environment, V\&W responsible for mobility, LNV responsible for agriculture, fisheries and nature development, BuZA responsible for foreign development aid and biodiversity and the Finance Ministry. ${ }^{7}$

Based on suggestions from the transition platforms a transition action plan has been formulated which contains the following goals:

$\triangleright-50 \% \mathrm{CO} 2$ in 2050 in a growing economy

$\triangleright$ An increase in the rate of energy saving to $1.5-2 \%$ a year

\footnotetext{
${ }^{7}$ EZ is the Ministry of Economic Affairs, VROM is the Ministry of Health, Spatial Planning and Environment, V\&W is the Ministry of Traffic and Water, LNV the Ministry of Agriculture and Nature, BUZA the Ministry of Foreign Affairs)
} 
$\triangleright$ The energy system getting progressively more sustainable

$\triangleright$ The creation of new business ${ }^{8}$

The transition action plan was prepared by the Taskforce energy transition, based on inputs form the platforms. With the action plan entitled "More with energy. Chances for the Netherlands" the Dutch energy transition approach went 'public'. In May 2006, in a television news-broadcasted event, it was presented by the chair person (Rein Willems, CEO of Shell Netherlands) to the Dutch public and political parties. It is a highly corporatist approach, which has been criticized on democratic grounds (Hendriks 2008). Interestingly, however it was government who enrolled business in it, and not the other way. It took a lot of persuasion of the Ministry of Economic Affairs to have business involved. It was EZ who took the initiative to create a platform by appointing a chair, whose task was to invite innovative business people to the platform, together with experts and people from civil society. In each platform there is someone from government serving as a "linking pin" with policy. Each platform has 10 to 15 members. They are selected by the chair on the basis of personal knowledge of, and visions related to, the theme in question; they are not invited as representatives of particular interests (Dietz et al. 2008, p. 223). Some of the platform members will chair temporary working groups comprising an ad hoc selection of experts, entrepreneurs and NGOs, which prepare or define solution directions or strategic processes for the platform theme. In this way, in each platform some 60 to 80 'leaders' are involved (Dietz et al. 2008, p. 223).

The task force only existed for less than 2 years, in which it produced two reports; the transition action plan (May 2006) and a set of recommendations (Dec 2006). It was superseded by the Regieorgaan Energietransitie Nederland (REN) created in 2008. The Regieorgaan is responsible for developing an overall vision for the energy supply (electricity and heat) in the Netherlands and to formulate a strategic agenda based on inputs of the platforms. ${ }^{9}$ In 2009 they will produce recommendations for policy, as part of an official advice, solicited by the Dutch government. The Regieorgaan is composed of 11 people: the chairs of the 7 transition platforms and 4 "independent members".

The transition platforms selected 31 transition paths. An overview of these is given in Appendix I, together with the self-stated goals and transition experiments.

\footnotetext{
${ }^{8}$ In 2009 the official goals for 2020 are: $2 \%$ rate of energy saving a year, $20 \%$ share for renewable energy and 30 reduction of $\mathrm{CO} 2$.

${ }^{9}$ The formal tasks of the Regieorgaan are: 1) to create a basis for support among public and private parties for the energy transition to stimulate the design, formulation and implementation of transition paths, 2) to actively stimulate the bundling of ambitions, ideas about possibilities, knowledge and experience of business, 3) to stimulate cohesion between the different activities of the energy transition and to guard and monitor progress, 4) to promote long-term planning for the energy transition and the development and implementation of transition paths, 5) to make recommendations to Ministers about the energy transition and the implementation of transition paths on the basis of monitoring, analysis and evaluations, 6) to identify, select and stimulate new developments, initiatives and innovations relevant to the energy transition, based on ambitions and competences of market actors and government energy transition goals, 7) to make recommendations to Ministers for what they can do in terms of policy interventions for the energy transition, 8) to evaluate the transition paths every 4 years, to actualize them and to make recommendations for an actualization of long-term plans, 8) to create a network of public and private partners for the promotion of clear communication between the parties of the energy transition and between the transition paths, 9) to promote information provision for the general public about the energy transition.
} 
The portfolio of transition paths contains technological innovation at different states of development. The Platforms Sustainable Mobility, Built Environment, and Chain Efficiency concentrate themselves on the accelerated introduction of available technologies; the other platforms oriented themselves more towards emerging technologies (such as 2 nd generation biofuels).

In the 2004-2007 period 160.2 million euro has been spend on the transition experiments and demonstration projects in the area of sustainable energy through the UKR and EOS-DEMO schemes. An overview of the expenditures over the 7 platforms can be found in Tables 1 and 2 .

In order to qualify for support under the UKR the experiments should

- be part of an official transition path

- involve stakeholders (beyond business) in an important way

- have explicit learning goals for each of the actors of the consortium.

In the period Oct $2007-$ Dec 200886 projects have been funded through various programmes. Total investments for these projects amounted to 191 million euro. The government contribution for these programmes was 56 million euro. The projects cover a wide range of transition paths, and not just a few (Table 3).

The production of sustainable energy is supported through the SDE (Stimulering Duurzame Energieproductie) instrument. For 2009 the total budget amounts to 2.585 million euro (this sum does not include support for offshore windpower). http:// www.senternovem.nl/sde/algemene_subsidie_informatie/index.asp

The transition approach goes beyond technology support. It is oriented at creation capabilities, networks and institutions for transitional change through the creation of agendas, partnerships, new instruments, and vertical and policy coordination are part of it. The IPE plays an important role in "taking initiatives", "connecting and strengthening initiatives", "evaluate existing policy and to act upon the policy advice from the Regieorgaan and transition platforms", to "stimulate interdepartmental coordination" and to "make the overall transition approach more coherent"

Table 1 Overview of transition experiment projects in the area of sustainable energy funded by the unique opportunities scheme (UKR) in the 2004-2007 period

Unique opportunities scheme(UKR)

\begin{tabular}{lcccr}
\hline Platform & $\begin{array}{l}\text { Projects } \\
\text { approved }\end{array}$ & $\begin{array}{l}\text { Investment amount } \times \\
\text { 1 million euro }\end{array}$ & $\begin{array}{l}\text { Subsidy amount } \times \\
\text { 1 million euro }\end{array}$ & $\begin{array}{l}\mathrm{CO}_{2} \text { reduction } \\
\text { in kton/year }\end{array}$ \\
\hline New gas & 22 & 316.7 & 45.7 & 1,647 \\
Sustainable electricity supply & 2 & 9.1 & 2.0 & 2 \\
Transport (sustainable mobility) & 10 & 150.1 & 10.8 & 1,053 \\
Green raw materials & 5 & 100.4 & 12.5 & 39 \\
Greenhouse as energy source & 1 & 111.0 & 4.0 & 90 \\
Chain efficiency & 7 & 260.2 & 42.1 & 377 \\
Built environment & 1 & 10.1 & 1.2 & 1 \\
Total & 48 & 957.8 & 118.3 & 3,211 \\
\hline
\end{tabular}

Energy Innovation Agenda (2008, p. 112) 
Table 2 Overview of demonstration projects in the area of sustainable energy funded under the EOSDEMO programme in the 2004-2007 period

Unique opportunities scheme(UKR)

\begin{tabular}{|c|c|c|c|c|c|}
\hline Platform & $\begin{array}{l}\text { Projects } \\
\text { approved }\end{array}$ & $\begin{array}{l}\text { Investment amount } \times \\
1 \text { million euro }\end{array}$ & $\begin{array}{l}\text { Subsidy amount } \times \\
1 \text { million euro }\end{array}$ & $\begin{array}{l}\mathrm{CO}_{2} \text { reduction } \\
\text { in kton/year }\end{array}$ & $\begin{array}{l}\text { Projects } \\
\text { approved }\end{array}$ \\
\hline New gas & 49 & 125.5 & 18.3 & 74 & 9,234 \\
\hline $\begin{array}{l}\text { Sustainable } \\
\text { electricity supply }\end{array}$ & 9 & 26.5 & 4.0 & 2 & 855 \\
\hline $\begin{array}{l}\text { Transport } \\
\text { (sustainable mobility) }\end{array}$ & 4 & 9.3 & 1.1 & 4 & 618 \\
\hline Green raw materials & 4 & 6.3 & 1.5 & 4 & 289 \\
\hline $\begin{array}{l}\text { Greenhouse as } \\
\text { energy source }\end{array}$ & 14 & 61.6 & 7.6 & 142 & 8,485 \\
\hline Chain efficiency & 16 & 50.1 & 9.4 & 46 & 2,793 \\
\hline Built environment & - & - & - & - & - \\
\hline Total & 96 & 279.3 & 41.9 & 273 & 22,274 \\
\hline
\end{tabular}

Energy Innovation Agenda (2008, p. 113)

(Staatscourant 25 Feb 2008, nr. 39, p. 29). The position of the energy transition approach within the policy framework for sustainable energy is given in Fig. 2.

As one can see the energy transition approach is but one element in the policy framework for sustainable energy, which is much wider and includes production subsidies, environmental covenants and green procurement policies at the demand side, various RTD policies and other policies at the supply side, policies for start ups, cluster policies and other sociotechnical alignment policies.

The whole approach is set up as a vehicle for sociotechnical change and policy change in a coordinated manner. This is evident from the following quote from policy makers Frank Dietz, Hugo Brouwer and Rob Weterings:

"It is clear that working on fundamental changes to the energy system can only be successful if the government adjusts its policy instrumentarium accordingly. This means that the policy for research and development, the stimulation of demonstration projects, and the (large-scale) market introduction must be brought in line with the selected transition pathways. In addition, the suggestions for new policies put forward by the platforms must be taken seriously. At this point, the government faces a major challenge, because much of the current policy was formulated based on the classic way of thinking that is characterized by a topdown approach and dominated by short-term objectives, implemented by fragmented and individually-operating departments and Ministries, on which market influences do not or hardly have any effect" (Dietz et al. 2008: 238)

It is also evident from the activities of the Regieorgaan and the platforms for 2009 (Table 4).

As one can see the platforms seek to produce advice, take stock of what has been achieved, they commission studies and are involved in all kind institutional alignment activities (also between the platforms). The platforms are currently 
Table 3 Government policy instruments for innovative transition projects

\begin{tabular}{|c|c|c|c|c|c|c|}
\hline $\begin{array}{l}\text { Government instrument } \\
\text { providing support to } \\
\text { innovative transition } \\
\text { projects } 2007-2008\end{array}$ & & Period & $\begin{array}{l}\text { Number } \\
\text { of projects } \\
\text { funded }\end{array}$ & $\begin{array}{l}\text { Number } \\
\text { of project } \\
\text { applications }\end{array}$ & $\begin{array}{l}\text { Subsidies } \\
(€)\end{array}$ & $\begin{array}{l}\text { Total } \\
\text { investments } \\
\text { (indicative) }\end{array}$ \\
\hline Demonstration demo & $1 \times$ & Oct $07-$ Jan 08 & 21 & 66 & $11,248,588$ & $96,000,000$ \\
\hline $\begin{array}{l}\text { Towards energy-neutral } \\
\text { homes UKR }\end{array}$ & $1 \times$ & Feb-Apr 08 & 15 & 42 & $7,500,000$ & $30,300,000$ \\
\hline Clean busses & $1 \times$ & Nov 07-May 08 & 6 & 9 & $10,000,000$ & $20,000,000$ \\
\hline $\begin{array}{l}\text { Fuelling stations } \\
\text { alternative fuels }\end{array}$ & $1 \times$ & May-Jun 08 & $\mathrm{pm}$ & 44 & $1,800,000$ & $5,000,000$ \\
\hline $\begin{array}{l}\text { Semi-closed greenhouse/ } \\
\text { other energy systems } \\
\text { MEI }\end{array}$ & $1 \times$ & Feb-Mar 08 & 17 & 20 & $13,206,145$ & $\begin{array}{l}40,000,000 \\
\quad \text { (indicative) }\end{array}$ \\
\hline $\begin{array}{l}\text { Heating/cooling in } \\
\text { industry SBIR }\end{array}$ & $1 \times$ & Sep-Dec 08 & 8 & 14 & 371.623 & \\
\hline Heating/cooling UKP & $1 \times$ & Sep-Dec 08 & Unknown yet & $\mathrm{pm}$ & $10,000,000$ & $\mathrm{pm}$ \\
\hline $\begin{array}{l}\text { Bio-innovative } \\
\text { products SBIR }\end{array}$ & $1 \times$ & Aug-Oct 08 & 20 & 47 & $1,800,000$ & nvt \\
\hline Total & $8 \times$ & & 86 & $242(3,0 \times$ more $)$ & $55,926,356$ & $\begin{array}{l}191,300,000 \\
\quad(3,3 \times \text { more })\end{array}$ \\
\hline
\end{tabular}

IPE werkplan 2008, pp. 6-7

working with municipal authorities and national government to create pilots for energy neutral living districts to learn about alternative energy systems (with the systems going beyond particular technologies from the platforms) and to create visibility for the energy transition.

\subsection{Front-runners desk}

An interesting initiative is the front-runners desk, created in 2004, designed to help innovative companies with problems encountered and to help policy to become more innovation friendly. Problems varied from difficulties with getting financial support (from government or private finance) to problems with getting permits. Between Jan 2004 and March 2006, 69 companies approached the desk to discuss problems. In 59\% of the cases, the problems were solved thanks to the intervention of the desk, in $12 \%$ of the cases the companies could not be helped, and in the remaining cases (29\%) the desk was still dealing with the issue at the time of the evaluation. An overview of the functions of the desk for innovators and policy is provided in the Table 5.

The government also funded an evaluation of 31 transition paths, to examine transition path specific "motors" and barriers.

\subsubsection{Budget and staffing}

From the 6 Ministries involved (Ministry of Economic Affairs, Ministry of Health, Spatial Planning and Natural Environment, Ministry of Traffic and Water, Ministry of Agriculture and nature, Ministry of Foreign Affairs, Ministry of Finance) more than 20 people are directly involved in the energy transition activities. In the government period 2007-2008 in total 130 innovative projects started with a total 


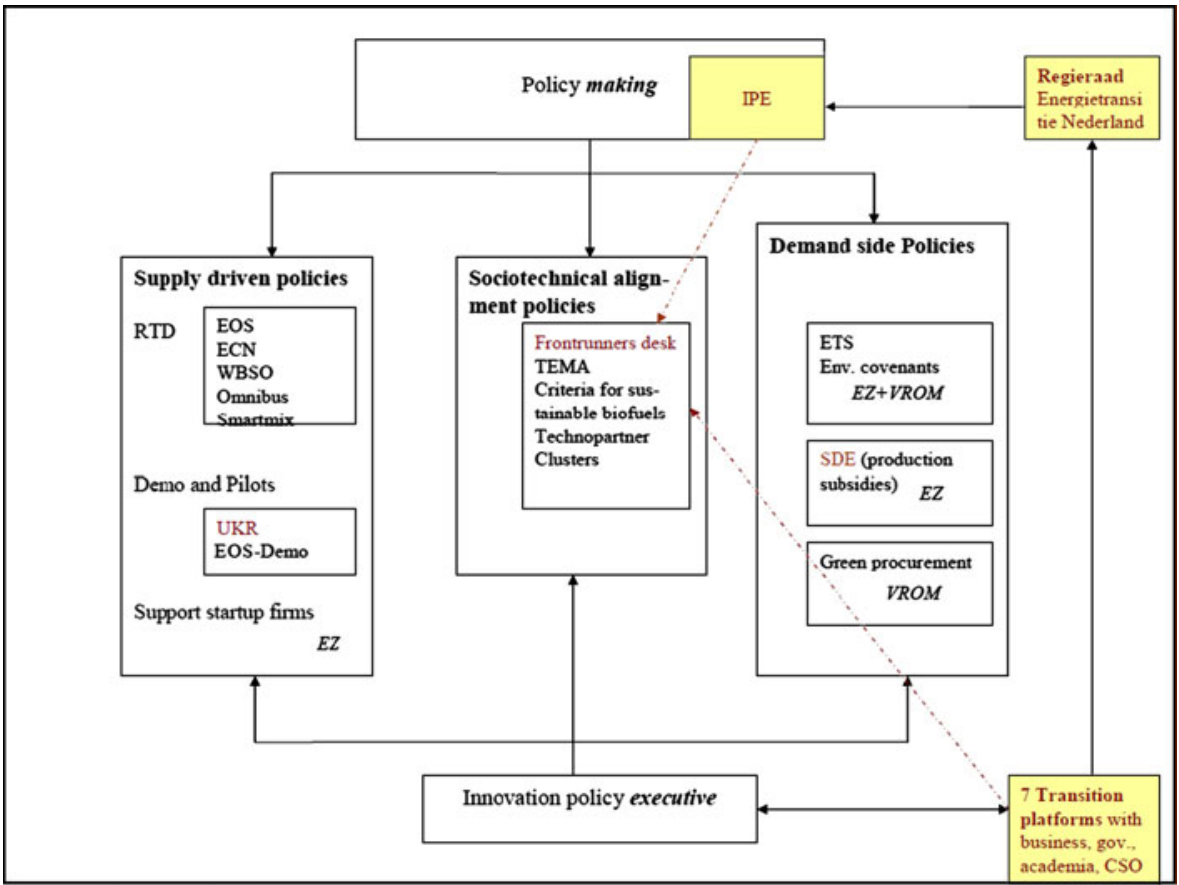

Source: Author

Fig. 2 Position of the energy transition approach within the Dutch policy framework for sustainable energy. Source: Author

investment sum of 800 million Euro. For the 2008-2012 period 438 million euro has been allocated for energy innovation research. In total the following sums of money have been allocated for cleaner energy and energy saving: 1,747 million euro in 2009, 1.898 million euro in 2010 and 1.898 million euro in 2011.

The Dutch energy transition approach covers the entire energy supply system (including clean coal) with the exception of nuclear energy. The energy innovation agenda formulated in 2008 is oriented towards the 7 themes of the energy transition. For each theme, the government has formulated specific activities.

For sustainable mobility the following activities are announced for the government period:

1. The creation of a programme to create the basic infrastructure for natural gas and green fuels (liquid and gaseous) for vehicles. A subsidy scheme for filling stations for alternative fuels will be created. The $2^{\text {nd }}$ generation of biofuels is prioritised for sustainable development reasons including a higher $\mathrm{CO} 2$ reduction effect. Together with market parties a new programme for pilots will be set up for innovative, sustainable drive systems and the use of biofuels in busses and trucks, plus the use of additives for fuel reduction and reduction of fine particles. Foreign experiences will be studied and lessons will be used.

2. The government will act as a launching customer for the use of innovative and sustainable vehicles and fuels. City distribution will be stimulated too. 
Table 4 Planned activities in 2009

Platform Planned activities in 2009

Regieorgaan

Green resources

Sustainable mobility

New gas

Chain efficiency

Sustainable electricity production

Built environment
- Production of an official advice on policy, in which they make recommendation for instrument choices

- To follow the implementation of sustainability criteria for biomass

- Position paper on CO2 allowances for biomass

- To launch an explorative study into the macroeconomic effects of biomass production and use in the Netherlands

- To develop a systematique for measuring green resources

- To make recommendations for fiscal treatment of clean vehicles

- To discuss the action plan on alternative mobility with leasing companies

- To examine how natural gas and green gas may pave the way for hydrogen

- Evaluate experiences with buss experiments funded in the first tender

- To offer advice on how public transport concessions may be used for innovation

- To assist in the implementation of 5 pilots about smart grids and electric mobility

- To launch or stimulate pilots for sustainable biofuels (high blends and biogas) and hydrogen in five cities in cooperation with Germany and Flanders in Belgium

- To investigate product-market-combinations for decentralised gas use

- To commission or undertake a study into the potential of gas motors and absorption heat pumps

- Starting the first phase of the programme for precision agriculture

- Working out a development plan for process intensification

- Formulate platform positions on off shore energy,

- rules for co-burning of biomass, cogeneration, and conditions for coal-fired plants

- Implementation the earlier formulated action plan Decentralised infrastructure (smart nets)

- To examine and utilise opportunities in blue energy

- Platform advice about the restructuring of existing business parcs

- Workplan (script) for achieving energy saving using a district-based approach

- Investigation of how local authorities may be involved, on a voluntary and less voluntary basis

Bloemlezing energietransitie, November 2008

3. The government will continue the innovation programme for clean busses. A $2^{\text {nd }}$ tender will be implemented. A programme for "trucks of the future" will be created geared towards the demonstration of very clean and silent trucks for city distribution.

4. In line with the EU Joint technology Initiative Fuel Cell and Hydrogen, large scale experiments will be undertaken in cooperation with EU partners. One possibility which is being considered is the creation of a corridor between the Randstad (west region of the Netherlands in which the 4 largest cities are located), NordrheinWestfalen (Germany) and Flanders (Belgium). In co-operation with local authorities and industrial partners a demonstration programme will be prepared. The hydrogen will be produced in a climate-neutral way in Rotterdam for use in the Amsterdam bus and shipping initiative. 
Table 5 Overview of functions of front runner desk for innovators and policy

Functions for innovators

Obtain financial support from existing instruments To make existing instruments more conducive

To get into contact with relevant agencies and government people

Overcoming legal problems and problems with permits

To widen their network and strengthen the organisational set up of the innovation trajectory

Business support and public relation help for the successful market introduction for innovation

Functions for policy

To improve policy coordination between ministries and within ministries

To stimulate case-sensitive implementation of existing and new policy

To stimulate policy development in areas of the innovation chain not well covered by policy

To be serviceable to business in a case-sensitive way

Weterings (2006)

5. The government will stimulate the creation of standards for intelligent transport systems (ITS). Special attention is given to electronic systems for mobility payment which will become the basis for future payment and funding of infrastructure. The government will investigate the consequences of an increased use of plug-in hybrids and other electric vehicles for the electricity grid and will execute a large-scale test at the level of a neighbourhood district.

6. The government will take steps towards a consistent and continuing fiscal support for sustainable vehicles and for transparent information supply about such vehicles for consumers. The national government will support the leasing market for sustainable vehicles.

7. The national government will work with Airport Schiphol for making Schiphol more sustainable.

Source: Innovatieagenda Energie (2008, pp. 40-41)

Technological and organisational capabilities are being created endogenously, alongside strategic knowledge and aligned policies. Alignment between sociotechnical developments and policy is being achieved in various ways: through the (programming) activities of transition platforms and taskforces, a frontrunners desk, specially commissioned research into the development of transition paths, the transitions knowledge centre (KCT), the competence centre for transitions (CCT), and transition experiments.

There are also regular interactions between transition researchers, practitioners and government. The government funded a 10 million social research programme on transitions. Researchers meet with practitioners at special network days and are involved in the government-funded innovation programmes for sustainable energy mobility, buildings, agriculture and health care. The author of this article was involved in a workshop with project managers of the Transumo programme, a 30 million programme for sustainable mobility involving 150 organisations. In the workshop project managers were asked to reflect on the following questions:

- Does the project offer a contribution to a societal problem (challenge)? Which challenge is this? 
- Is it informed by a vision of sustainable mobility? Is it designed to learn about this vision?

- Is it part of a transition path? If so, what path?

- Is it oriented towards demonstration or learning? Does it learn about sustainability aspects, markets, how various actors may be enrolled and how the project may be scaled up?

These questions helped them to reflect on their project in a novel way.

\subsubsection{Policy integration and cooperation}

The energy transition is something for all domains and layers of government. It involved various ministries and many different dossiers. For example, in the area of sustainable mobility a task force for mobility management has been set up to think about ways to reduce congestion not through road pricing but through flexible working times, teleworking, promoting the use of bicycles and public transport for commuting, which are being supported by business and workers. IPE is engaged in coordination activities for offshore wind power: allocation of spots, safety, financing of power cables. On this topic they have some influence, on other topics such as environmental regulations and fiscal measures it does not have great influence.

It is also wrong to think that the platform's choices are fully limitative for innovation. The official paths have an advantage but they do not foreclose other paths. New initiatives may emerge outside the platforms through parliament or because certain powerful parties in society are able to secure policy support for it. An example is the programme for battery electric vehicles which was defined by others. A coalition of NGOs, business (Essent, Better Place), finance (ING, Rabo) and the Urgenda (a coalition for sustainability action) successfully lobbied Ministers and parliament to give special support to BEVs. The platform for sustainable mobility was critical about the programme, it considered the hybrid-route more promising given the present state of development of batteries and thought that the goal of 1 million battery electric cars in 2025 was unrealistic but is working constructively with this initiative.

On the whole policy coordination has improved in the last 6 years. For example, battery electric vehicles, hybrid electric vehicles and low-emission other vehicles are subject to special fiscal treatment. ${ }^{10}$ There is more co-operation between Ministries and between government, business, research and civil society. There is also more co-operation of national initiatives and regional initiatives.

The platforms are also working together more than before. For example, the platform for sustainable electricity supply (working group decentralised infrastructure) is investigating issue of charging stations for (plug-in hybrid) electric vehicles: technical standards for vehicle charge points, the capacity implications of a big fleet of (plug-in hybrid) for the electricity systems with different technical configurations, how to avoid

\footnotetext{
${ }^{10}$ In the Netherlands many vehicles are leased from companies. People driving a leased vehicle must add $25 \%$ of the value of the car to their income before taxes and pay taxes over this extra sum. If you lease a battery electric vehicle, $10 \%$ of the value of the car is subjective to income taxes; for hybrid electric vehicles it is $14 \%$. Charging points are up for a fiscal advantage of $20 \%$. The tax incentives for cars proved very effective: in the first 5 months of 2009, 7456 hybrid electric cars were sold in the Netherlands, an increase of $63 \%$ compared to the same period in 2008. Between 2008 and 2009 the number of HEV doubled: from 11,000 to 23,000 .
} 
peak loads through load management. For now they are focussing on grid-to-vehicle and not on the reverse issue of vehicle-to-grid. All this is done as part of a four-year action plan

To foster the "flexible use of instruments" for fostering energy innovation a special arrangement is created, the temporary energy arrangement market and energy innovation (Tijdelijke Energie Regeling Markt en Innovatie). IPE encouraged the development of it and was instrumental in aligning it with the innovation agenda for energy (Werkplan 2009 of IPE). These instruments complement the European Emissions Trading System for carbon emissions and the sectoral covenants for energy use reduction. Control policies are not part of the transition approach as such, in the future they might become part of it but they are now outside it.

The transition approach for system innovation is a long-term approach for achieving carbon reductions which complements short-term policies for obtaining carbon reductions through the use of available energy saving options and carbon-low technologies. For achieving carbon reductions of 96 Mton by 2020 a "three waves" approach is used. The first wave consists of the picking of low-hanging fruit (low-cost carbon reduction options). The second wave consists of options that are almost mature, the third wave of options that require a great deal of $R \& D$ and experimentation. Examples of third wave options are $\mathrm{CO} 2$ capture and storage and the use of biological raw materials in the chemical industry (biorefining) (Energy Innovation Agenda 2008, p. 22). The three waves approach is given in Fig. 3.

Anticipated carbon reductions from the ( 3 waves) Clean and Efficient programme are given in Table 6.

\section{Reflection and tentative evaluation}

In the Netherlands the national government is using a "transition approach" for making the transition to sustainable energy, drawing on ideas about transition

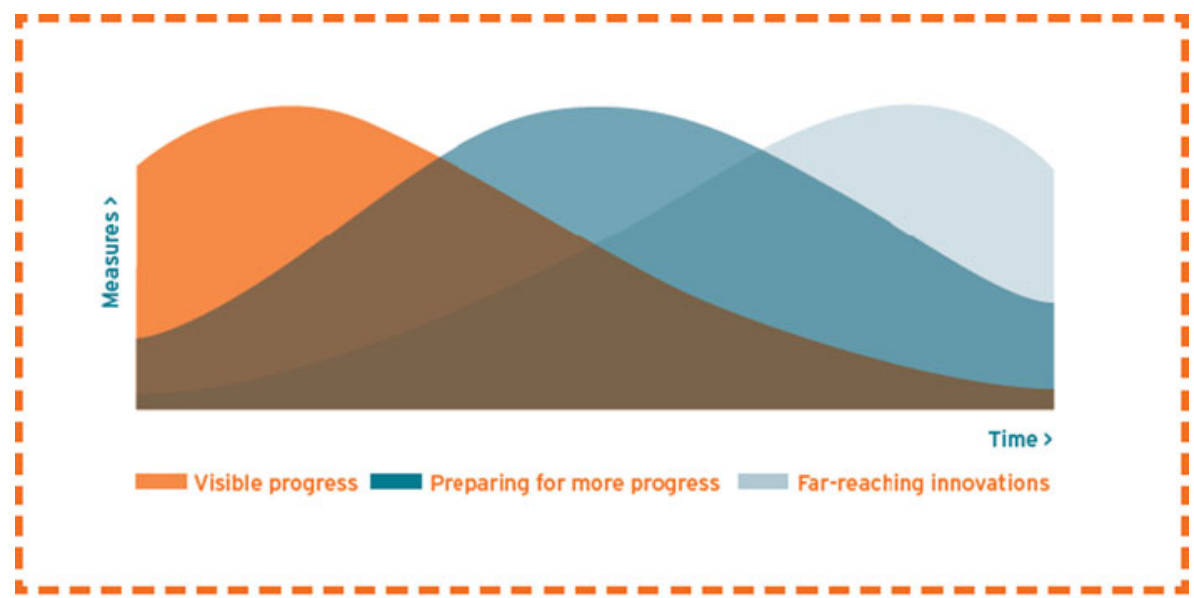

Source: Energy Innovation Agenda (2008, p. 22)

Fig. 3 The 3 waves approach for achieving carbon reductions. Source: Energy Innovation Agenda (2008, p. 22) 
Table 6 Anticipated carbon reductions from the Clean and Efficient programme

\begin{tabular}{lrrlllll}
\hline in Mton/year & 1990 & 2005 & $\begin{array}{l}2010 \\
\text { Unchanged } \\
\text { policy }\end{array}$ & $\begin{array}{l}2020 \\
\text { Unchanged } \\
\text { policy }\end{array}$ & $\begin{array}{l}\text { With clean and } \\
\text { efficient according } \\
\text { to ECN/MNP }\end{array}$ & $\begin{array}{l}\text { With clean and } \\
\text { efficient cabinet } \\
\text { goals, }\end{array}$ & $\begin{array}{l}\text { Cabinet's reduction } \\
\text { goal compared to } \\
\text { unchanged policy }\end{array}$ \\
\hline $\begin{array}{l}\text { Built } \\
\begin{array}{l}\text { Industry/ } \\
\text { electricity }\end{array}\end{array}$ & 30 & 39 & 27 & 26 & $20-23$ & $15-20$ & $6-11$ \\
$\begin{array}{l}\text { Traffic } \\
\text { Agriculture }\end{array}$ & 93 & 101 & 105 & 131 & 75 & $70-75$ & $56-61$ \\
$\begin{array}{l}\text { Other greenhouse } \\
\text { gases }\end{array}$ & 54 & 36 & 40 & 47 & $30-34$ & $30-34$ & $13-17$ \\
$\begin{array}{l}\text { Total } \\
\text { CDM/JI }\end{array}$ & 215 & 212 & 215 & 246 & $158-167$ & $5-6$ & $1-2$ \\
\hline
\end{tabular}

Energy Innovation Agenda (2008, p. 20), based on calculations by ECN/MNP

management articulated by Dutch scientists, based on insights from innovation and transition studies (the work of Rip, Schot, Kemp and Geels, Jacobsson) and evolutionary economics (Nelson and Winter, van den Bergh, Bleischwitz and Hinterberger). The Dutch energy transition approach is a corporatist approach for innovation, enrolling business in processes of transitional change that should lead to a more sustainable energy system. A broad portfolio of options is being supported. A portfolio of options is generated in a bottom-up, forward looking manner in which special attention is given to system innovation. Both the technology portfolio and policies should develop with experience. The approach is forward-looking and adaptive. One might label it as guided evolution with variations being selected in a forward-manner by knowledgeable actors willing to invest in the selected innovations, the use of strategic learning projects (transition experiments) and the use of special programmes and instruments. It is a Darwinist approach which relies on market selection but does not do so in a blind way.

Initially, the energy transition was a self-contained process, largely separated from existing policies for energy savings and the development of sustainable energy sources. It is now one of the pillars of the overall government approach for climate change. Internationally, contacts have been established with Finland, the UK, Austria and Denmark, which are using similar approaches. The Ministries of Environment (VROM) and Economic Affairs (EZ) are collaborating with each other on energy innovation issues, both national and internationally.

It is an approach of ecological modernisation in which special attention is given to system innovation, as a new element. Options to make the existing energy system more sustainable (such as carbon capture and sequestering) are not excluded. They are also receiving attention and support. It bears noting that despite the attention to system-innovation it is entirely possible that coal-fired power plants and nuclear power plants will be build in the years to come, even when nuclear energy is not a transition path (clean coal is an official transition option but carbon capture and sequestering is not a proved technology yet). In the privatised energy markets, electricity producers can opt for those options. The commitment to privatisation and 
liberal energy markets is not helpful to the energy transition process (Kern and Howlett 2009).

In the eyes of the Dutch government, the energy approach so far is a success, by being able to exploit latent business interests in sustainable energy. Alternative energy (use) systems are worked at in a prudent manner through special learning projects and programmes. Policies for innovation are combined with policies to achieve immediate carbon reductions, through carbon trading, covenants about energy savings and a support scheme for sustainable energy production.

The transition literature sparked a debate about possibilities for managing transitions and the DRIFT transition management model ${ }^{11}$. Smith et al. (2005) together with Jacob (2007) criticise the idea of transitions occurring through niche development processes, pointing to other pathways and the need for regime-changing policies to complement innovation support schemes.

Shove and Walker (2007) are openly critical of the "transition through modernisation" idea and transition management approach. They doubt the ability of societies to transform themselves and criticise the central role given to technical change in societal transitions (arguing that culture and social practices have been neglected).

Transition management is also criticised for being an elitist and technocratic approach of modernisation (Hendriks 2008; see also Smith and Kern 2007) for the reason that none of the platforms is democratically chosen and the public not really being involved. They say the process is dominated by regime actors.

Meadowcroft (2009) questions the possibility for achieving closure through willful transition policies, saying that transitions are messy and open processes.

At a workshop in Germany where I presented the Dutch transition approach, the approach was criticized for not delivering much on renewable energy and greenhouse gas reductions. It is true that The Netherlands have been underachieving in terms of renewable energy and $\mathrm{CO} 2$ emission reduction. The share of renewable electricity in the Netherlands (9\% in 2010) is far below the European average of $22 \%$ for the EU15 and 21\% for the EU27 (see Appendix II). CO2 levels have not fallen. In $2008 \mathrm{CO} 2$ emissions were higher than in 2007. In terms of CO2 equivalents a $3 \%$ reduction has been achieved in greenhouse gas emissions, which is half of the $6 \%$ reduction that is required to achieve according to the Kyoto protocol. It is wrong to blame the Dutch energy transition approach for this as it is just one element of sustainable energy policy. The transition approach is an approach for achieving long-term benefits, not short-term reductions in $\mathrm{CO} 2$. One may question whether a broad portfolio is not too broad. A broad portfolio may be something for a big country such as Germany and not something for a small country with limited resources. The dominance of incumbents has been acknowledged by Hugo Brouwer, the director of the energy transition process but no steps have been undertaken against this.

\footnotetext{
${ }^{11}$ In Kemp (2009) the various criticisms leveled against transition management are discussed more extensively.
} 
Germany moved much further into the direction of a low-carbon economy than the Netherlands. But this owed more to political circumstances: the willingness to stimulate renewable energy. The German experience shows that market pull can stimulate not only diffusion but also innovation.

One important conclusion for policy is that for bringing about a transition something more is needed than innovation support. For instance for achieving a transition to a low-carbon economy, environmental taxes and other carbon reducing policies are needed, as pointed out by environmental economists such as Ekins and Bleischwitz. It was hoped by this author that the commitment to sustainability transitions helps to make such choices, but this did not happen. As countries are unlikely to unilaterally introduce carbon-restraining policies for economic fears, it is important to have international carbon-reducing policies. The European Emission Trading system is an important development in this respect. The Netherlands is relying on ETS and sectoral covenants for achieving reductions in greenhouse gas reductions.

As an innovation support approach the Dutch transition management model is a sophisticated approach which fits with modern innovation system thinking which says that policy should be concerned with 1) management of interfaces, (2) organizing (innovation) systems, (3) providing a platform for learning and experimenting, (4) providing an infrastructure for strategic intelligence and (5) stimulating demand articulation, strategy and vision development (Smits and Kuhlman 2004; see also Grin and Grunwald 2000).

By relying on adaptive portfolio's two possible mistakes of sustainable energy policy possibly may be prevented, 1) the promotion of short-term options which comes from the use of technology-blind generic support policies such as carbon taxes or cap and trade systems (which despite being "technology-blind" are not technology neutral at all because they favour low-hanging fruit and regimepreserving change (Jacobsson et al. 2009), and 2) picking losers (technologies and system configurations which are suboptimal) through technology-specific policies. Here we should add to say that there are good reasons for relying on market-based instruments (to achieve carbon reductions at a low cost) and for engaging in technology-support but that a combination of such policies is desirable.

When engaging in technology specific support policies one task for policy is to not fall prey to special interests, hypes and undue criticisms. The support given to the first generation biofuels turned out to be wrong. The philosophy of guided evolution used in the Netherlands appears a good one as the transition to a lowcarbon economy really consists of two challenges: to reduce carbon emissions and to contain the side-effects of low-carbon energy technologies, whether nuclear, wind power, or systems of carbon capturing and sequestering. All new energy technologies come with specific dangers and hazards, which have to be anticipated and addressed. For sustainable energy there are no technical fixes, nor are there perfect instruments. There is a need for policy to be more concerned with system change. The capacity to do so has to be created. It can be created in different ways. The Dutch model described in this article is one possible way. It is not a substitute for control policies such as environmental taxes and regulations, which remain necessary. 


\section{Appendix I}

Table 7 Overview of transition platforms, pathways and experiments

Platforms $\quad$ Pathways

\section{Chain efficiency}

Goal: savings in the annual use of energy in production chains of:

- 40 à $50 \mathrm{PJ}$ by 2010

- 150 à 180 PJ by 2030

- 240 à 300 PJ by 2050

\section{Green resources}

Goal: to replace $30 \%$ of fossil fuels by green resources by 2030

\section{New gas}

Goal: to become the most clean and innovative gas country in the world

\section{Sustainable mobility}

Goals:

- Factor 2 reduction in GHG emissions from new vehicles in 2015

- Factor 3 reduction in GHG emissions for the entire automobile fleet 2035

\section{Sustainable electricity}

Goal: A share of renewable energy of $40 \%$ by 2020 and a CO2-free energy supply by 2050

\section{Built environment}

Goal: by 2030 a $30 \%$ reduction in the use of energy in the built environment, compared to 2005

\section{Energy-producing greenhouse}

Goals for 2020:

- Climate-neutral (new) greenhouses
KE 1: Renewal of production systems

KE 2: sustainable paper chains

KE 3: sustainable agricultural chains

GG 1: sustainable biomass production

GG 2: biomass import chain

GG 3: Co-production of chemicals, transport fuels, electricity and heat

GG 4: production of $\mathrm{SNG}$

GG 5: Innovative use of biobased raw materials for non-food/non-energy applications and making existing chemical products and processes more sustainable

NG 1: Energy saving in the built environment

NG 2: Micro and mini CHP

NG 3: clean natural gas

NG 4: Green gas

DM 1: Hybrid and electric vehicles

DM 2: Biofuels

DM 3: Hydrogen vehicles

DM 4: Intelligent transport systems

DE 1: Wind onshore

DE 2: Wind offshore

DE 3: solar PV

DE 4: centralised infrastructure

DE 5: decentralised infrastr

GO 1: Existing buildings

GO 2: Innovation

GO 3: Regulations

KE 1: Solar heating

KE 2: Use of earth heat 
Table 7 (continued)

\section{Platforms}

- $48 \%$ reduction in $\mathrm{CO}_{2}$ emissions

- Producer of sustainable heat and energy

- A significant reduction in fossil fuel use

\section{Pathways}

KE 3: Biofuels

KE 4: Efficient use of light

KE 5: Cultivation strategies and energy-low crops

KE 6: Renewable electricity production

$\mathrm{KE} 7$ : Use of $\mathrm{CO} 2$

Kern and Smith (2008), http://www.creatieve-energie.nl/ and internet search

\section{Appendix II}

Table 8 Electricity generated from renewable sources (\% of gross electricity consumption)

\begin{tabular}{|c|c|c|c|c|c|c|c|c|c|}
\hline & 2000 & 2001 & 2002 & 2003 & 2004 & 2005 & 2006 & 2007 & 2010 \\
\hline European Union (27 countries) & 13.8 & 14.4 & 12.9 & 12.9 & 13.9 & 14.0 & 14.6 & 15.6 & 21.0 \\
\hline European Union (15 countries) & 14.6 & 15.2 & 13.5 & 13.7 & 14.7 & 14.5 & 15.3 & 16.6 & 22.0 \\
\hline Belgium & 1.5 & 1.6 & 1.8 & 1.8 & 2.1 & 2.8 & 3.9 & 4.2 & 6.0 \\
\hline Bulgaria & 7.4 & 4.7 & 6.0 & 7.8 & 8.9 & 11.8 & 11.2 & 7.5 & 11.0 \\
\hline Czech Republic & 3.6 & 4.0 & 4.6 & 2.8 & 4.0 & 4.5 & 4.9 & 4.7 & 8.0 \\
\hline Denmark & 16.7 & 17.3 & 19.9 & 23.2 & 27.1 & 28.3 & 26.0 & 29.0 & 29.0 \\
\hline Germany (including ex-GDR from 1991) & 6.5 & 6.5 & 8.1 & 8.2 & 9.5 & 10.5 & 12.0 & 15.1 & 12.5 \\
\hline Estonia & 0.3 & 0.2 & 0.5 & 0.6 & 0.7 & 1.1 & 1.4 & 1.5 & 5.1 \\
\hline Ireland & 4.9 & 4.2 & 5.4 & 4.3 & 5.1 & 6.8 & 8.5 & 9.3 & 13.2 \\
\hline Greece & 7.7 & 5.2 & 6.2 & 9.7 & 9.5 & 10.0 & 12.1 & 6.8 & 20.1 \\
\hline Spain & 15.7 & 20.7 & 13.8 & 21.7 & 18.5 & 15.0 & 17.7 & 20.0 & 29.4 \\
\hline France & 15.1 & 16.5 & 13.7 & 13.0 & 12.9 & 11.3 & 12.5 & 13.3 & 21.0 \\
\hline Italy & 16.0 & 16.8 & 14.3 & 13.7 & 15.9 & 14.1 & 14.5 & 13.7 & 22.55 \\
\hline Cyprus & 0.0 & 0.0 & 0.0 & 0.0 & 0.0 & 0.0 & 0.0 & 0.0 & 6.0 \\
\hline Latvia & 47.7 & 46.1 & 39.3 & 35.4 & 47.1 & 48.4 & 37.7 & 36.4 & 49.3 \\
\hline Lithuania & 3.4 & 3.0 & 3.2 & 2.8 & 3.5 & 3.9 & 3.6 & 4.6 & 7.0 \\
\hline Luxembourg (Grand-Duché) & 2.9 & 1.6 & 2.8 & 2.3 & 3.2 & 3.2 & 3.4 & 3.7 & 5.7 \\
\hline Hungary & 0.7 & 0.8 & 0.7 & 0.9 & 2.3 & 4.6 & 3.7 & 4.6 & 3.6 \\
\hline Malta & 0.0 & 0.0 & 0.0 & 0.0 & 0.0 & 0.0 & 0.0 & 0.0 & 5.0 \\
\hline Netherlands & 3.9 & 4.0 & 3.6 & 4.7 & 5.7 & 7.5 & 7.9 & 7.6 & 9.0 \\
\hline Austria & 72.4 & 67.2 & 66.1 & 53.1 & 58.7 & 57.4 & 56.6 & 59.8 & 78.1 \\
\hline Poland & 1.7 & 2.0 & 2.0 & 1.6 & 2.1 & 2.9 & 2.9 & 3.5 & 7.5 \\
\hline Portugal & 29.4 & 34.2 & 20.8 & 36.4 & 24.4 & 16.0 & 29.4 & 30.1 & 39.0 \\
\hline Romania & 28.8 & 28.4 & 30.8 & 24.3 & 29.9 & 35.8 & 31.4 & 26.9 & 33.0 \\
\hline Slovenia & 31.7 & 30.5 & 25.4 & 22.0 & 29.1 & 24.2 & 24.4 & 22.1 & 33.6 \\
\hline Slovakia & 16.9 & 17.9 & 19.2 & 12.4 & 14.4 & 16.7 & 16.6 & 16.6 & 31.0 \\
\hline Finland & 28.5 & 25.7 & 23.7 & 21.8 & 28.3 & 26.9 & 24.0 & 26.0 & 31.5 \\
\hline Sweden & 55.4 & 54.1 & 46.9 & 39.9 & 46.1 & 54.3 & 48.2 & 52.1 & 60.0 \\
\hline United Kingdom & 2.7 & 2.5 & 2.9 & 2.8 & 3.7 & 4.3 & 4.6 & 5.1 & 10.0 \\
\hline
\end{tabular}


Open Access This article is distributed under the terms of the Creative Commons Attribution Noncommercial License which permits any noncommercial use, distribution, and reproduction in any medium, provided the original author(s) and source are credited.

\section{References}

Bergek A, Jacobsson S, Carlsson B, Lindmark S, Rickne A (2008) Analyzing the functional dynamics of technological innovation systems: a scheme of analysis. Res Policy 37:407-429

Berkhout F, Smith A, Stirling A (2004) Technological regimes, transition contexts and the environment. In: Elzen B, Geels F, Green K (eds) System innovation and the transition to sustainability: theory, evidence and policy. Edward Elgar, Cheltenham, pp 48-75

Dietz F, Brouwer H, Weterings R (2008) Energy transition experiments in the Netherlands. In: van den Bergh J, Bruinsma F (eds) Managing the transition towards renewable energy: theory and practice from local, regional and macro perspectives. Edward Elgar, Cheltenham, pp 217-244

Dirven J, Rotmans J, Verkaik A (2002) Samenleving in transitie: Een vernieuwend gezichtspunt, Innovatienetwerk Agrocluster en Groene Ruimte, Den Haag

Energy Innovation Agenda (2008) Government white paper, The Hague

Foxon F, Reed MS, Stringer LC (2009) Governing long-term social-ecological change: what can the adaptive management and transition management approaches learn from each other? Environmental Policy and Governance 19:3-20

Freeman C, Louçã F (2001) As times goes by. From the industrial revolutions to the information revolution. Oxford University Press, Oxford

Geels FW (2002) Technological transitions as evolutionary reconfiguration processes: a multi-level perspective and a case-study. Res Policy 31(8/9):1257-1274

Geels FW (2004) From sectoral systems of innovation to socio-technical systems: insights about dynamics and change from sociology and institutional theory. Res Policy 33(6-7):897-920

Geels FW (2005) Technological transitions, a co-evolutionary and socio-technical analysis. Edward Elgar, Cheltenham

Geels FW (2006) Co-evolutionary and multi-level dynamics in transitions: the transformation of aviation systems and the shift from propeller to turbojet (1930-1970). Technovation 26(9):999-1016

Geels FW (2007) Transformations of large technical systems: a multi-level analysis of the Dutch highway system (1950-2000). Sci Technol Hum Val 32(2):123-149

Geels FW, Kemp R (2007) Dynamics in socio-technical systems: typology of change processes and contrasting case studies. Technol Soc 29(4):441-455

Geels FW, Raven RPJM (2007) Socio-cognitive evolution and co-evolution in competing technical trajectories: biogas development in Denmark (1970-2002). Int J Sustain Dev World Ecol 14(1):63-77

Geels FW, Schot J (2007) Typology of socio-technical transition pathways. Res Policy 36:399-417

Genus A, Coles A-M (2008) Rethinking the multilevel perspective of technological transitions. Res Policy 37(9):1436-1445

Grin J (2006) Reflexive modernization as a governance issue - or: designing and shaping re-structuration. In: Voß JP, Bauknecht D, en Kemp R (eds) Reflexive governance for sustainable development. Edward Elgar, Cheltenham, pp 57-81

Grin J, Grunwald A (eds) (2000) Vision assessment: shaping technology in the 21 st century society. Towards a repertoire for technology assessment. Springer, Berlin-Heidelberg

Hekkert MP, Suurs RAA, Negro SO, Kuhlmann S, Smits REHM (2007) Functions of innovation systems: a new approach for analysing technological change. Technol Forecast Soc Change 74(4):413-432

Hendriks C (2008) On inclusion and network governance: the democratic disconnect of Dutch energy transitions. Public Adm 86(4):1009-1031

Holtz G, Brugnach M, Pahl-Wostl C (2008) Specifying "regime"-a framework for defining and describing regimes in transition research. Technol Forecast Soc Change 75:623-643

Hoogma R, Kemp R, Schot J, Truffer B (2002) Experimenting for sustainable transport. The approach of strategic niche management. EF\&N Spon, London

Jacob K (2007) Comment: management of industrial transformation: potentials and limits from a political science perspective. In: Lehmann-Waffenschmidt $M$ (ed) Innovations towards sustainability. Conditions and consequences. Physica Verlag, Heidelberg, pp 95-100 
Jacobsson S, Bergek A (2004) Transforming the energy sector: the evolution of technological systems in renewable energy technology. Ind Corp Change 13(5):815-849

Jacobsson S, Bergek A, Finon D, Lauber V, Mitchell C, Toke D, Verbruggen A (2009) EU renewable energy support policy: faith or facts. Energ Pol 37:2143-2146

Kemp R (2009) Eco-innovations and transitions. Econ Fonti Energ Ambiente 52(1):103-124, Special issue on Heterodox environmental economics

Kemp R, Loorbach D (2006) Transition management: a reflexive governance approach. In: Voss J-P, Bauknecht D, Kemp R (eds) Reflexive governance for sustainable development. Edward Elgard, Cheltenham, pp 103-130

Kemp R, Rotmans J (2009) Transitioning policy: co-production of a new strategic framework for energy innovation policy in the Netherlands. Policy Sci 42:303-322

Kemp R, Loorbach D, Rotmans J (2007a) Transition management as a model for managing processes of co-evolution. Int J Sustain Dev World Ecol 14:78-91 (special issue on (co)-evolutionary approach to sustainable development)

Kemp R, Loorbach D, Rotmans J (2007b) Assessing the Dutch energy transition policy: how does it deal with dilemmas of managing transitions? Journal Environ Policy Plan 9:315-331

Kern F, Smith A (2008) Restructuring energy systems for sustainability? Energy transition policy in the Netherlands. Energy Policy 36(11):4093-4103

Kern F, Howlett M (2009) Implementing transition management as policy reforms: a case study of the Dutch energy sector. Policy Sci 42:391-408

Landes D (1969) The unbound Prometheus: technological and industrial development in Western Europe from 1750 to the present. Cambridge University Press, Cambridge

Loorbach D (2007) Transition management. New mode of governance for sustainable development. International Books, Utrecht

Markard J, Truffer B (2008) Technological innovation systems and the multi-level perspective: towards an integrated framework. Res Policy 37(4):596-615

Meadowcroft J (2009) What about the politics? Sustainable development, transition management, and long term energy transitions. Policy Sci 42(4):323-340

Mumford L (1934) Technics and civilization. Harcourt Brace and Co., New York

National Research Council (1999) Our common journey: a transition toward sustainability. National Academy Press, Washington DC

Rammel C, van der Bergh JCJM (2003) Evolutionary policies for sustainable development: adaptive flexibility and risk minimising. Ecol Econ 47:121-133

Reckwitz A (2002) Toward a theory of social practices; a development in culturalist theorizing. Eur J Soc Theory 5(2):243-263

Rip A, Kemp R (1996) Towards a theory of socio-technical change. Mimeo University of Twente, Enschede

Rip A, Kemp R (1998) Technological change. In: Rayner S, Malone L (eds) Human choice and climate change, vol 2. Resources and Technology, Batelle, Washington DC, pp 327-399

Rosenberg N (1982) Inside the black box. Technology and economics. Cambridge University Press, Cambridge

Rotmans J (2005) Maatschappelijke innovatie. Tussen droom en werkelijkheid staat complexiteit, oratie EUR (Societal innovation. Between dream and reality stands complexity, inaugural speech Erasmus University Rotterdam)

Rotmans J, Kemp R (2008) Detour ahead. A response to Shove and Walker about the perilous road of transition management. Environ Plann A 40:1006-1014

Rotmans J, Kemp R, van Asselt M, Geels F, Verbong G, Molendijk K (2000) Transities \& Transitiemanagement. De casus van een emissiearme energievoorziening. (Transitions and transition management. The case of an clean energy system, final report of study "Transitions and Transition management" for the 4th National Environmental Policy Plan (NMP-4) of the Netherlands, October 2000, ICIS \& MERIT, Maastricht

Rotmans J, Kemp R, van Asselt M (2001) More evolution than revolution. Transition management in public policy. Foresight 3(1):15-31

Schmandt J, Ward CH (eds) (2000) Sustainable development: the challenge of transition. Cambridge University Press

Shove E (2004) Sustainability, system innovation and the laundry. In: Geels F, Green K, Elzen B (eds) System innovation and the transition to sustainability: theory, evidence and policy. Edward Elgar, Cheltenham, pp 76-94

Shove E, Walker G (2007) CAUTION: transitions ahead! Environ Plann A 39:763-770 
Shove E, Walker G (2008) Transition management and the politics of shape shifting. Environ Plann A 40:1012-1014

Smith A, Kern F (2007) The transitions discourse in the ecological modernisation of the Netherlands. Working Paper Series, no. 160

Smith A, Kern F (2009) The transitions story line in Dutch environmental policy. Env Polit 18(1):78--98

Smith A, Stirling A (2008) Social-ecological resilience and socio-technical transitions: critical issues for sustainability governance. STEPS Centre Working Paper. University of Sussex

Smith A, Stirling A, Berkhout F (2005) The governance of sustainable sociotechnical transitions. Res Policy 34:1491-1510

Smits R, Kuhlman S (2004) The rise of systemic instruments in innovation policy. International Journal of Foresight and Innovation Policy (IJFIP) 1(1/2):4-32

Spaargaren G (2003) Sustainable consumption: a theoretical and environmental policy perspective. Soc Nat Resour 16:687-701

Spaargaren G, Mommaas H, van den Burg S, Maas L, Drissen E, Dagevos H, Bargeman B, Putman L, Nijhuis J, Verbeek D, Sargant E (2007) Duurzamer Leefstijlen en Consumptiepatronen: een theoretisch perspectief voor de analyse van transitieprocessen binnen consumptiedomeinen. Onderzoeksrapport TMB-project, Environmental Policy Group Wageningen Universiteit/Milieu Natuur Planbureau/Tilburg Universiteit Telos/Landbouw Economisch Instituut

Staatscourant (2008) Instellingsbesluit van het Regieorgaan Energietransitie Nederland, Staatscourant 25 Feb 2008, nr. 39, p.39

Verbong G (2000) De Nederlandse overheid en energietransities: een historisch perspectief.' (Translation: The Dutch government and energy transitions: a historical perspective), background document for the report "Transitions and transition management" (Rotmans et al. 2000), Eindhoven, The Netherlands

Verbong GPJ, Geels FW (2007) The ongoing energy transition: lessons from a socio-technical, multi-level analysis of the Dutch electricity system (1960-2004). Energ Pol 35(2):1025-1037

Verbong GPJ, Geels FW (2008) Pathyways for sustainability transitions in the electricity sector: a multilevel analysis and empirical illustration IEEE. IEEE, Rotterdam

Weterings (2006) Quick scan koplopersloket. Een evaluatie van werkwijze, output en effecten, Competentie Centrum Transities 